\title{
Application of Cowdung and Sawdust as Biostimulants for Enhanced Bioremediation of Diesel Contaminated Soil
}

\author{
*WOKEM, VC; MADUFURO, C \\ Department of Microbiology, University of Port Harcourt, P.M.B 5323, Port Harcourt, Nigeria \\ *Corresponding Author Email: chineduvin@yahoo.com,Tel: 08130306131
}

\begin{abstract}
The study was aimed at exploring the use of cow dung (CD) and sawdust (SD) as bio stimulants for enhanced ex-situ bioremediation of diesel fuel contaminated soil. Results of the microbial populations in a gram of soil showed that diesel polluted soil amended with $\mathrm{CD}$ had the highest total culturable heterotrophic bacterial (TCHB) population range $\left(1.42 \times 10^{6}-1.56 \times 10^{7} \mathrm{Cfu} / \mathrm{g}\right)$, total fungal $(\mathrm{TF})\left(1.0 \times 10^{6}-1.60 \times 10^{7} \mathrm{Cfu} / \mathrm{g}\right)$, hydrocarbon utilizing bacteria (HUB) $\left(4.5 \times 10^{6}-2.05 \times 10^{7} \mathrm{Cfu} / \mathrm{g}\right)$ and hydrocarbon utilizing fungi (HUF) $\left(3.5 \times 10^{6}-1.3 \times 10^{7} \mathrm{Cfu} / \mathrm{g}\right)$ respectively during the study. Diesel polluted soil amended with SD had lower TCHB populations $\left(1.32 \times 10^{6}-2.0 \mathrm{x}\right.$ $\left.10^{7} \mathrm{Cfu} / \mathrm{g}\right)$, TF $\left(6.0 \times 10^{6}-3.6 \times 10^{7} \mathrm{Cfu} / \mathrm{g}\right)$, HUB $\left(5.4 \times 10^{6}-1.28 \times 10^{7} \mathrm{Cfu} / \mathrm{g}\right)$ and $\mathrm{HUF}\left(1.2 \times 10^{6}-2.0 \times 10^{6} \mathrm{Cfu} / \mathrm{g}\right)$ respectively, while the microbial populations in option C (control) were TCHB $\left(1.14 \times 10^{6}-1.18 \times 10^{7} \mathrm{Cfu} / \mathrm{g}\right)$, TF $(1.7 \times$ $\left.10^{6}-7.0 \times 10^{6} \mathrm{Cfu} / \mathrm{g}\right)$, HUB $\left(4.2 \times 10^{6}-7.8 \times 10^{6} \mathrm{Cfu} / \mathrm{g}\right)$ and HUF $\left(1.1 \times 10^{6}-5.0 \times 10^{7} \mathrm{Cfu} / \mathrm{g}\right)$ respectively. Changes in $\mathrm{pH}$ values showed reductions in $\mathrm{CD}(7.10-6.20)$ and SD $(5.78-4.88)$ amended soils. Percentage losses in TPH from chromatography results showed diesel polluted soil amended with CD (61.30\%), SD (41\%) and control (4.11\%) respectively. Characterization and identification tests of bacterial isolates revealed that a microbial consortium comprising of the following HUB genera; Bacillus, Pseudomonas, Proteus, Alcaligenes, Klebsiella, Enterobacter, Citrobacter, Corynebacterium and Escherichia coli was implicated in the biodegradation process. Similarly, the HUF encountered were Fusarium, Aspergillus, Microsporium, Penicilium and Mucor. The results suggest that the application of cow dung as biostimulant will enhance the bioremediation of diesel contaminated soil than the application of sawdust.
\end{abstract}

\section{DOI: https://dx.doi.org/10.4314/jasem.v24i1.7}

Copyright: Copyright $($ C) 2020 Wokem and Madufuro. This is an open access article distributed under the Creative Commons Attribution License (CCL), which permits unrestricted use, distribution, and reproduction in any medium, provided the original work is properly cited.

Dates: Received: 30 November 2019; Revised: 20 December 2019; Accepted: 23 December 2019

Keyword: Cowdung, Sawdust, Bioremediation, Biostimulation

Petroleum diesel fuel is produced from fractional distillation of crude oil (ITRC, 2014). It is composed of about $75 \%$ saturated hydrocarbon (primarily paraffin) and 25\% aromatic hydrocarbons (including naphthalenes and alkl benzenes) (ITRC, 2014; Wellington et al., 1995). Diesel fuel is used to power diesel engines (Wellington and Asmus, 1995). The use of diesel fuel introduces considerably large quantity of the product into the environment, leading to the pollution of the air, water, agricultural and recreational areas (Knothe et al., 2006). It has a severe environmental impact on the ecosystem by harming or killing wildlife and plants. Components of diesel which are hydrocarbons have been known to belong to the family of caricnogens and neurotoxic organic pollutant (ATSDR, 1995; Bundy et al., 2002; Nora et al., 2013; Hawrot-Paw et al., 2015; Sylvia, 2019). Soil contamination by diesel has been found to result from petroleum extraction, refining, transportation, improper usage, accidents, leakage of tanks and pipeline ruptures. Petroleum products contamination is responsible for alteration of soil physicochemical properties and hurdles in nutrient cycling. It increases the heavy metal contents in soil (Akpoveta and
Osakwe, 2014) affecting the $\mathrm{pH}$, electrical conductivity and many soil properties (Barua et al., 2011; Zaki et al., 2014; Chibuike and Obiora, 2014).The application of conventional remediation methods such as dredging, mechanical removal and chemical treatment can be costly and may further destroy the environment by making toxic hydrocarbons and more bio-available (Hilyard et al., 2008). Bioremediation is the biological natural technique which employs the use of microorganisms to enhance the elimination or detoxifying of hydrocarbon pollutants into non-toxic residues (Banat, 2004; Vidali, 2001). Biostimulation a process of bioremediation involves the addition of appropriate nutrients to hydrocarbon polluted environment to stimulate the indigenous microbial flora, thereby enhancing the microbial degradation of the pollutants (Vidali, 2001; Mukred et al., 2008; Omoni et al., 2015). Previous studies have employed the use of agricultural wastes as nutrient supplements in bioremediation of hydrocarbon polluted environments. (Ijah and Antai, 2003; Bento et al., 2005; Dadrasnia and Agamuthu, 2010; Ibiene et al., 2011; Dadrasnia and Agamuthu, 2013; Leera et al., 
2018) The present study therefore, was aimed at the application of cowdung and sawdust as nutrient supplements in enhancing the bioremediation of diesel contaminated agricultural soil.

\section{MATERIALS AND METHODS}

Sample Collection: The diesel sample used in the study was obtained from Oando PLC/Unipetrol Nigeria PLC, Petrol Filling station Headquarter located in Port Harcourt, Rivers State, Nigeria. Soil sample was collected from the agricultural farm land of Faculty of Agriculture, University of Port Harcourt using soil augar. The topsoil was sampled $15 \mathrm{~cm}$ deep at different points and mixed thoroughly for homogencity into a clean polythene bag and transported to the laboratory for analyses. Cowdung was collected into clean polythene bag from the Faculty of Agriculture Demonstration Farm (Animal farm) of the University of Port Harcourt. It was composted for 2 weeks to reduce its pathogenic impact on the environment. Sawdust a by-product of wood cutting or sawing was obtained from a timber market located in Alakahia community in Obio/Akpor Local Government of Rivers State, Nigeria.

Reagents: All reagents employed in this study were of analytical grade and were obtained from Sigma Chemical Company, St. Louis Missouri, USA and BDH Chemical, Ltd, Poole, England. All Microbiological Media used were products of oxoid and Difco Laboratories, England. Filter paper (Whatman No. 1) was obtained from WER Bauston Ltd, London. Bonny light crude oil used for HUB and HUF tests was obtained from Port Harcourt Refinery Company, Eleme, Rivers State, Nigeria.

Experimental Setup: Two hundred and fifty (250)g of soil sample was weighed separately and placed in three clean plastic containers, labeled (A, B and C). Each was polluted with $100 \mathrm{ml}$ of diesel. To set A, 50g of oven dried and mashed cowdung (CD) was added, to set $\mathrm{B}, 50 \mathrm{~g}$ of oven dried sawdust (SD) was added, while set $\mathrm{C}$ was not amended with any organic waste which served as the control. Each set was mixed thoroughly with wooden spatula as to obtain homogenized mixture and enhance aeration. They were allowed to stand at room temperature $\left(28 \pm 2^{\circ} \mathrm{C}\right)$. Samples for microbiological and physicochemical analyses were collected for day 0,14 and 28 from set $\mathrm{A}, \mathrm{B}$, and the control set $\mathrm{C}$.

Enumeration of Total Culturable Heterotrophic Bacterial and Total Fungal Counts: The total culturable heterotrophic bacterial (TCHB) populations of soil samples were determined using spread plate method on nutrient agar (NA) (Oxoid) (APHA, 2005).
A serial ten-fold dilution was prepared using $1 \mathrm{~g}$ of soil and $0.1 \mathrm{ml}$ of $10^{-4}$ and $10^{-5}$ dilutions were inoculated and plated in triplicates. Plates were properly labelled and incubated at $37^{\circ} \mathrm{C}$ for $24 \mathrm{~h}$ (Chikere et al., 2013). For total fungal (TF) counts, $1.0 \mathrm{ml}$ of aliquot dilutions $\left(10^{-4}\right.$ and $\left.10^{-5}\right)$ were inoculated ad spread on Potato Dextrose Agar (PDA) plates (APHA, 2005) in triplicates by means of sterile bent glass rod and incubated at $30^{\circ} \mathrm{C}$ for $3-7$ days. Chloramphenicol antibiotic was added to the PDA to inhibit bacterial growth.

Enumeration of Hydrocarbon Utilizing Bacterial (HUB) and Hydrocarbon Utilizing Fungal (HUB) counts: For HUB population, appropriate dilutions $\left(10^{-4}-10^{-5}\right)$ of soil suspension (1g of soil homogenized in $0.85 \%$ of normal saline) was plated out in triplicates on Bushnell-Haas agar (Sigma-Aldrich, USA) plates modified with $10 \% \mathrm{NaCl}$. Hydrocarbon was supplied through the vapour phase transfer technique by placing sterile Whatman No.1 filter paper saturated with $5 \mathrm{ml}$ Bonny light crude oil in the inside lid of each plate kept in an inverted position and incubated at $37^{\circ} \mathrm{C}$ for 48h (Amanchukwu et al., 1989). For enumeration of HUF, the same procedure was followed, except that chloramphenicol antibiotics was incorporated into the BushHell-Haas agar medium to suppress growth of bacteria and incubated at $30^{\circ} \mathrm{C}$ for 3-7days.

Isolation and Identification of HUB and HUF: Culturable bacterial isolates of HUB and HUF were sub-cultured onto NA plates and incubated at $28 \pm 2^{\circ} \mathrm{C}$ for $24 \mathrm{~h}$. Discrete colonies were further sub-cultured onto slant NA in Bijou bottles and incubated at $28 \pm 2^{\circ} \mathrm{C}$ for $24 \mathrm{~h}$. The NA slant cultures were stored in the refrigerator at $4^{0} \mathrm{C}$ as pure stock cultures for subsequent characterization and identification. HUB isolates were identified by use of standard characterization tests known using the determination schemes of Bergey and Holt(1994) and Cheesbrough, (2006).Similarly, moulds were identified through their cultural as well as microscopic features using lacophenol cotton blue method, (Obire et al., 2008; David, et al., 2007).

Determination of Physicochemical parameters: Physicochemical parameters of polluted and unpolluted soil samples analyzed included $\mathrm{pH}$, total organic nitrogen, potassium, phosphorus and total petroleum hydrocarbon (TPH). They were determined using methods adopted from Stewart et al., (1994). For TPH, Gas Chromatography (GC) (HP 5890, Hewlett Packard, Avondale, PA, USA) equipped with flame ionization detector (FID) was employed. Soil sample for TPH analysis was extracted with methylene chloride. One micro litre $(1 \mu \mathrm{L})$ of the extract was 
injected and eluted in the calibrated GC. The peak areas were quantified as TPH concentration of soil samples. American Society for Testing Materials (ASTM, E-1945-1998). Percentage loss in TPH was calculated as:

$\%$ loss in TPH $=\frac{T P H \text { at day } 0-T P H \text { day } 28}{T P H \text { at day } 0} \times 100$

\section{RESULTS AND DISCUSSION}

Results of total culturable heterotrophic bacterial (TCHB) and total fungal (TF) populations of unpolluted soil, diesel polluted soil stimulated with $\mathrm{CD}$ and diesel polluted soil stimulated with $\mathrm{SD}$ are presented in Table 1. The result indicates that the diesel polluted soil stimulated with $\mathrm{CD}$ had the highest TCHB populations than the unpolluted and polluted soil stimulated with SD samples, while polluted soil stimulated with SD had the highest TF count. Tables 2 and 3 shows the bacterial and fungal genera isolated and identified in diesel polluted soil, diesel polluted soil stimulated with $\mathrm{CD}$ and diesel polluted soil stimulated with SD. Changes in total culturable heterotrophic bacteria (TCHB), total fungal (TF), Hydrocarbon utilizing bacteria (HUB) and Hydrocarbon utilizing fungal (HUF) populations during the bioremediation period are illustrated in Figs. 1-4. The results showed that the microbial populations were increasing during the period from day 0 to day 28 with the soil stimulated with cowdung having the highest bacterial and fungal counts (Figs. $1-4)$.

Table 1: TCHB, HUB, TF and HUF populations of unpolluted soil, polluted soil stimulated with cow dung and diesel polluted soil stimulated with sawdust samples during the bioremediation

\begin{tabular}{lllll}
\hline Samples & $\begin{array}{l}\text { TCHB } \\
\text { (Cfu/g) }\end{array}$ & $\begin{array}{l}\text { HUB } \\
\text { (Cfu/g) }\end{array}$ & $\begin{array}{l}\text { TF } \\
\text { (Cfu/g) }\end{array}$ & $\begin{array}{l}\text { HUF } \\
\text { (Cfu/g }\end{array}$ \\
\hline UPS (control) & $6.8 \times 10^{6}$ & $3.6 \times 10^{6}$ & $1.1 \times 10^{6}$ & $92.24 \times 10^{6}$ \\
DPS+CD & $9.4 \times 10^{6}$ & $3.8 \times 10^{6}$ & $1.2 \times 10^{6}$ & $3.1 \times 10^{6}$ \\
DPS+SD & $8.4 \times 10^{6}$ & $3.7 \times 0^{6}$ & $2.2 \times 10^{6}$ & $2.6 \times 10^{5}$ \\
\hline
\end{tabular}

Key: UPS = Unpolluted soil, $D P S+C D=$ Polluted soil stimulated with Cow dung, DPS $+S D=$ Polluted soil stimulated with Sawdust, $C f u / g=$ Colony forming unit per gram of soil.

Table 2: Bacterial isolates identified in diesel polluted soil, diesel polluted soil stimulated with CD and diesel polluted soil stimulated with SD samples during the bioremediation experiment

\begin{tabular}{|c|c|c|c|}
\hline Bacterial genera & DPS & DPS+CD & DPS+SD \\
\hline Bacillus & + & + & + \\
\hline Pseudomonas & & + & - \\
\hline Klebsiella & + & - & - \\
\hline Alcaligenes & + & - & _- \\
\hline Enterobacter & + & & - \\
\hline Corrynebacterium & - & + & - \\
\hline Citrobacter & - & + & \\
\hline Eschenshia & - & - & + \\
\hline
\end{tabular}

$(\overline{+)}$ positive, seen, (-) negative, not seen, DPS $=$ Diesel Polluted Soil, DPS $+\mathrm{CD}=$ Diesel Polluted soil stimulated with Cow dung, $\mathrm{DPS}+\mathrm{SD}=$ Diesel Polluted soil stimulated with Sawdust
Table 3: Fungal isolates identified in diesel polluted soil, diesel polluted soil with cow dung and saw dust samples during the bioremediation experiment

\begin{tabular}{llll}
\hline Bacterial genera & DPS & DPS+CD & DPS+SD \\
\hline Fusarium & - & + & + \\
Aspergillus & + & + & - \\
Microsporium & + & - & + \\
Penicillium & - & - & + \\
Mucor & - & + & + \\
\hline
\end{tabular}

$(+)$ positive, seen, (-) negative, not seen, DPS = Diesel Polluted Soil, $D P S+C D=$ Diesel Polluted Soil stimulated with Cowdung, $D P S+S D=$ Diesel Polluted stimulated with Sawdust

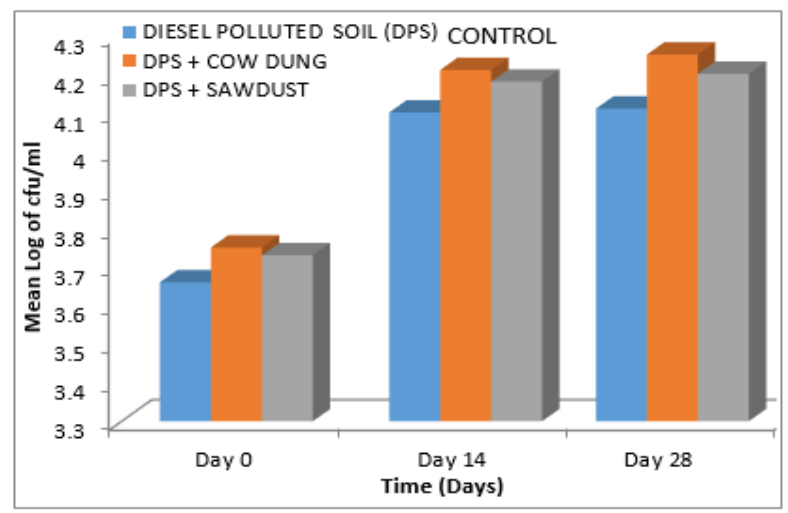

Fig. 1 Changes in Total Culturable Heterotrophic Bacterial (TCHB) populations during the study period

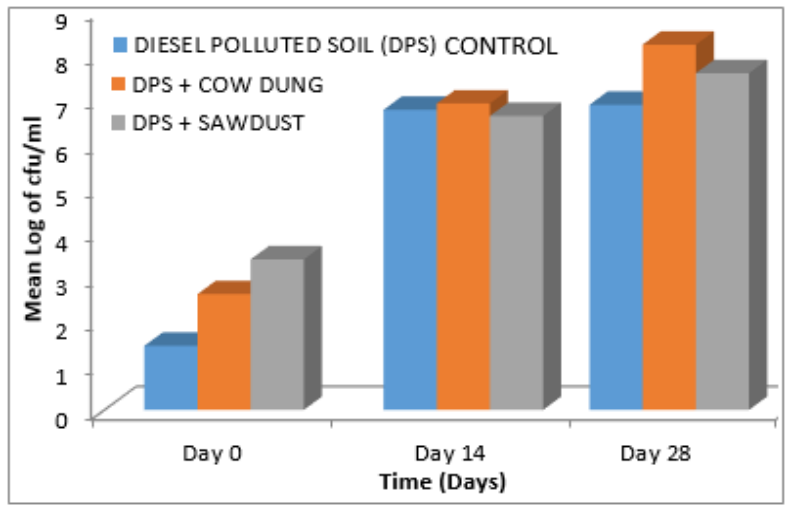

Fig. 2 Changes in Total Fungal (THF) populations during the study period

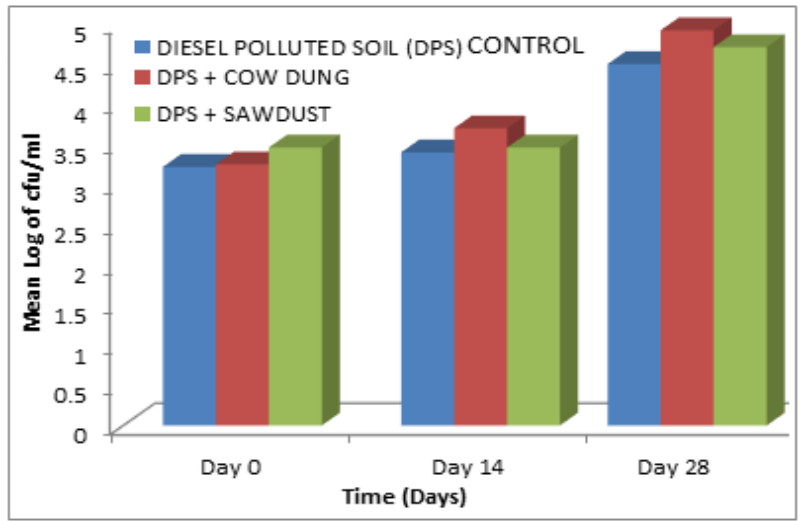

Fig. 3 Changes in hydrocarbon utilizing bacterial (HUB) populations during the study period 


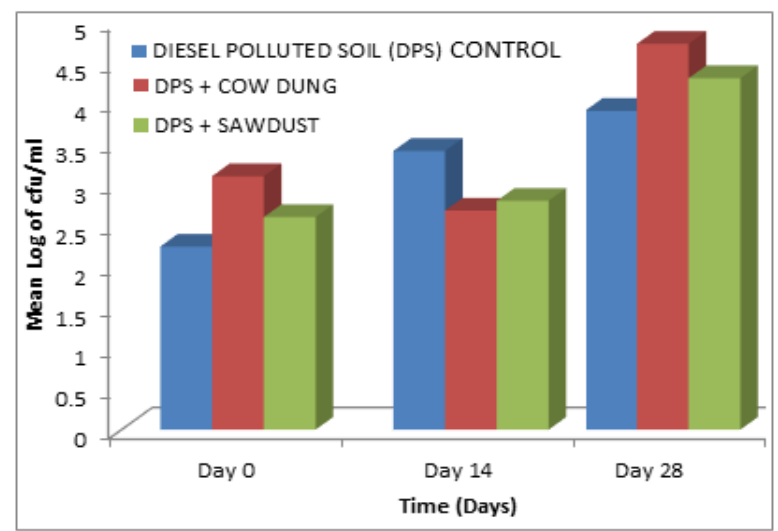

Fig. 4 Changes in hydrocarbon utilizing fungal (HUF) populations during the study period

Table 4: Changes in physiochemical parameters during the study

\begin{tabular}{|c|c|c|c|}
\hline Days & DPS (control) & $\mathrm{DPS}+\mathrm{CD}$ & $\mathrm{DPS}+\mathrm{SD}$ \\
\hline A & \multicolumn{3}{|l|}{ Changes in pH } \\
\hline $\mathbf{0}$ & 6.20 & 7.10 & 5.78 \\
\hline 14 & 6.10 & 7.0 & 5.68 \\
\hline 28 & 5.60 & 6.20 & 4.88 \\
\hline B & \multicolumn{3}{|c|}{ Changes in Nitrogen (\%) } \\
\hline $\mathbf{0}$ & 3.89 & 14.20 & 0.85 \\
\hline 14 & 3.79 & 14.10 & 0.75 \\
\hline 28 & 3.29 & 13.3 & 0.35 \\
\hline $\mathbf{C}$ & \multicolumn{3}{|c|}{ Changes in phosphorus (mg/kg) } \\
\hline $\mathbf{0}$ & 0.48 & 2.79 & 0.11 \\
\hline 14 & 0.38 & 2.69 & 0.09 \\
\hline 28 & 0.13 & 0.09 & 0.04 \\
\hline D & \multicolumn{3}{|c|}{ Changes in potassium content (mg/kg) } \\
\hline $\mathbf{0}$ & 11.74 & 18.33 & 28.53 \\
\hline 14 & 11.64 & 18.13 & 28.03 \\
\hline 28 & 10.14 & 17.33 & 27.3 \\
\hline
\end{tabular}

Table 5: Percentage (\%) losses in TPH of polluted soil and stimulated soil samples during the bioremediation period

\begin{tabular}{lllr}
\hline Soil type & $\begin{array}{l}\text { DAY 0 } \\
(\%)\end{array}$ & $\begin{array}{l}\text { DAY14 } \\
(\%)\end{array}$ & \multicolumn{2}{l}{$\begin{array}{l}\text { DAY28 } \\
(\%)\end{array}$} \\
\hline DPS (Control) & 0 & 3.63 & 4.11 \\
DPS+CD & 12.09 & 40.82 & 61.30 \\
DPS+SD & 6.75 & 22.65 & 40.69 \\
\hline
\end{tabular}

DPS $=$ Diesel polluted soil, DPS $+\mathrm{CD}=$ diesel polluted soil stimulated with cow dung, DPS $+\mathrm{SD}=$ diesel polluted soil stimulated with sawdust.

Changes in physicochemical parameters of the unstimulated diesel polluted soil and the diesel polluted soil stimulated with cow dung and sawdust during the bioremediation period are presented in Table 4. Generally, the results showed considerable decreases in all the physicochemical parameters analyzed in both the diesel polluted soil stimulated with cow dung and sawdust. The percentage losses in TPH of the diesel polluted soil and the stimulated soil samples during the bioremediation period are presented in Table 5. From the results, it reveals that $\%$ loss in TPH was higher in soil stimulated with cow dung $(61.30 \%)$ while that of soil stimulated with sawdust was $40.69 \%$ at day 28 .

Table 6: TPH remaining after each monitoring period

\begin{tabular}{llll}
\hline Treatment option & $\begin{array}{l}\text { Day 0 } \\
\text { (ppm) }\end{array}$ & $\begin{array}{l}\text { Day 14 } \\
\text { (ppm) }\end{array}$ & $\begin{array}{l}\text { Day 28 } \\
\text { (ppm) }\end{array}$ \\
\hline DPS (Control) & $14,409.32$ & $13,885.64$ & $13,816.25$ \\
DPS+CD & $12,665.91$ & $8,527.09$ & $5,575.18$ \\
DPS+SD & $13,435.95$ & $11,145.31$ & $8,545.99$ \\
\hline
\end{tabular}

DPS $=$ diesel polluted soil, DPS $+\mathrm{CD}=$ diesel polluted soil stimulated with cow dung, DPS+SD = diesel polluted soil stimulated with saw dust.

Figs. 5-10 shows the chromatograms of TPH fractions obtained for un-stimulated diesel polluted soil samples for day 0 and diesel polluted soil samples stimulated with cow dung and saw dust at day 0 and 28 respectively.

Fig. 5 is the chromatograms of TPH fractions of unstimulated (control), soil, indicating the extent of the different carbon fractions of the diesel polluted soil at day 0. While Figs. 6-7 shows the chromatograms of diesel polluted soil stimulated with $\mathrm{CD}$ and SD indicating the extent of the different carbon fractions of the diesel polluted soil at day 0. Figs. 8-10 shows that of day 28. From the results of the microbial populations of diesel polluted soil stimulated with cow dung (CD) sample and diesel polluted soil stimulated with sawdust (SD) samples used in this study, it is observed that $\mathrm{CD}$ had higher total culturable heterotrophic bacterial (TCHB) population (9.4 x $\left.10^{6} \mathrm{cfu} / \mathrm{g}\right)$ than the SD sample $\left(8.4 \times 10^{6} \mathrm{cfu} / \mathrm{g}\right)$ Table 1.This could be attributed to difference in nutrient composition of cow dung and sawdust. Cow dung is known to contain more organic nutrients as a result of degradative bacteria in rumen of cows, thereby having more organic nutrients supporting increase in microbial growth (Obire, et al., 2008; Adebusoye et al., 2007). The higher total fungal (TF) counts observed in the SD sample could be the high cellulose content of saw dust being product of plant (Obire et al., 2008; Ali et al., 2011). 


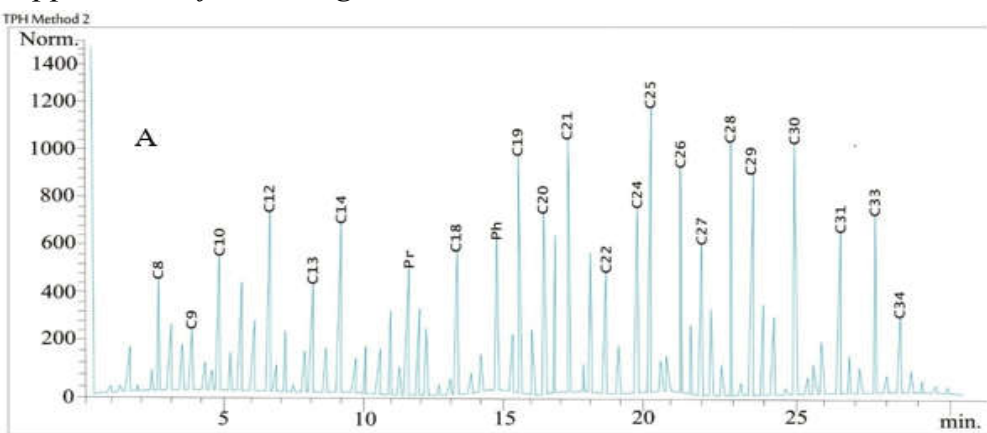

Fig. 5 Chromatogram of Total petroleum hydrocarbon (TPH) fractions of diesel polluted soil sample for day 0 .

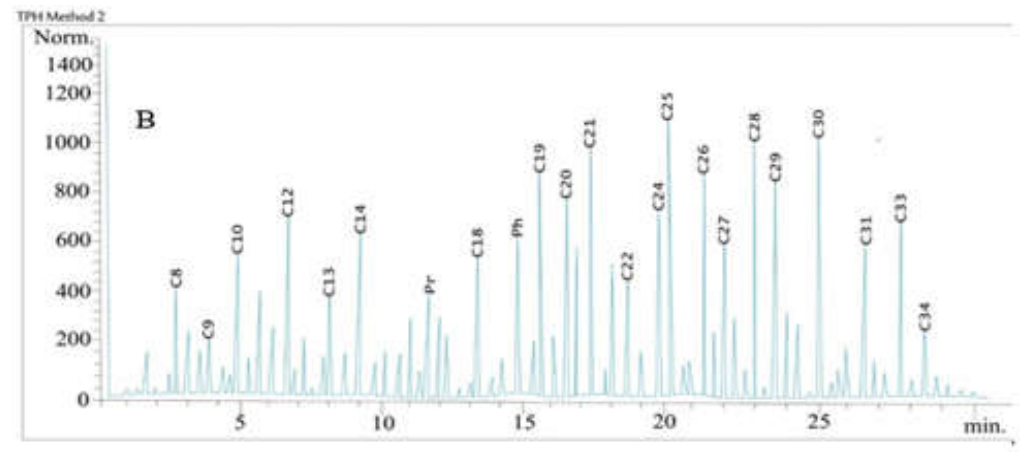

Fig. 6 Chromatogram of Total petroleum hydrocarbon (TPH) fractions of diesel polluted soil sample stimulated with cow dung for day 0 .

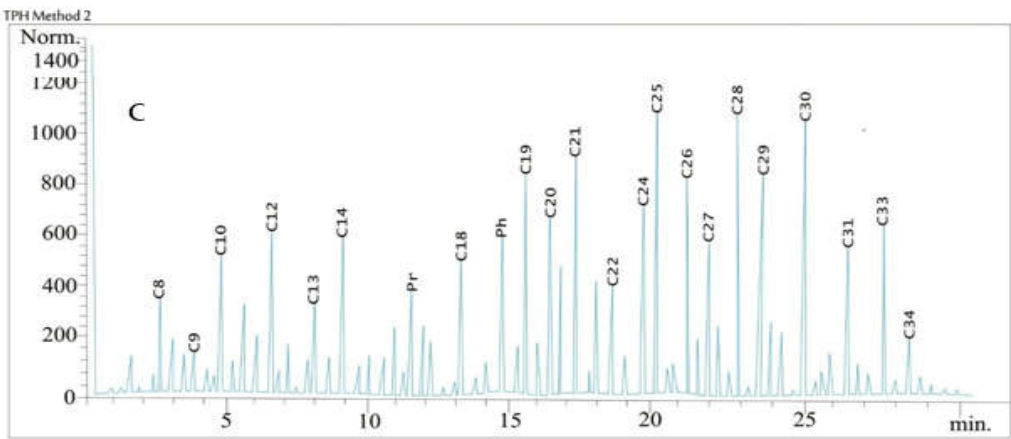

Fig. 7 Chromatogram of Total petroleum hydrocarbon (TPH) fractions of diesel polluted soil sample stimulated with sawdust for day 0 .

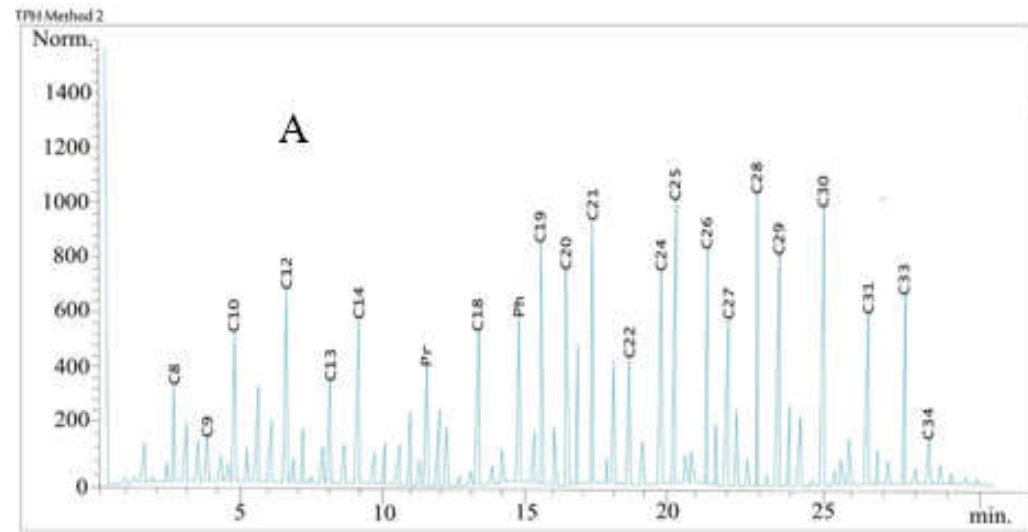

Fig. 8 Chromatograms of (A): Total petroleum hydrocarbon (TPH) fractions of unstimulated diesel polluted soil sample for day 28 .
There were appreciable increase in the microbial counts during the period of study, with the diesel polluted soil stimulated with cow dung showing highest counts in the TCHB, TF, HUB and HUF counts respectively (Figs. 1-4). This is attributable to the positive effects of organic nutrient supplement on enhanced bioremediation of petroleum hydrocarbon impacted environment. These results agrees with previous studies on enhanced bioremediation of impacted media (Ibiene et al., 2011; Agarry et al., 2012; Abioye et al., 2012; Chukwudozie, 2013; Omoni, et al., 2015).

The GC profile results revealed that $\mathrm{C}_{1}-\mathrm{C}_{7}$ straight chain hydrocarbon fractions were non-existent in all the soil samples (un-stimulated control and stimulated). While the heavier fractions $\mathrm{C}_{8}-\mathrm{C}_{34}$ were detected in both control and stimulated soil samples (Figs. 5-10). However, the two stimulants (cow dung and sawdust) were able to reduce the $\mathrm{C}_{8-}$ $\mathrm{C}_{34}$ hydrocarbon fractions appreciably at different rates during the study period, the highest reduction in the fraction was obtained with cow dung stimulated diesel polluted soil (DPS $+\mathrm{CD})$ at day 28 with TPH concentration remaining $5575.18 \mathrm{ppm}$. The unstimulated soil samples (control) remained $\quad 13,816.25 \mathrm{ppm}$ hydrocarbon concentration (Table $6)$. The more volatile and short chain hydrocarbon fractions were easily degraded or removed from the impacted soil by natural attenuation process. Studies have shown that the remaining components, which were not readily degraded, can still posse high environmental risk to the immediate vicinity of the area in which they remained or persisted (Gong et al., 2008; Macnaughton et al., 1999). 


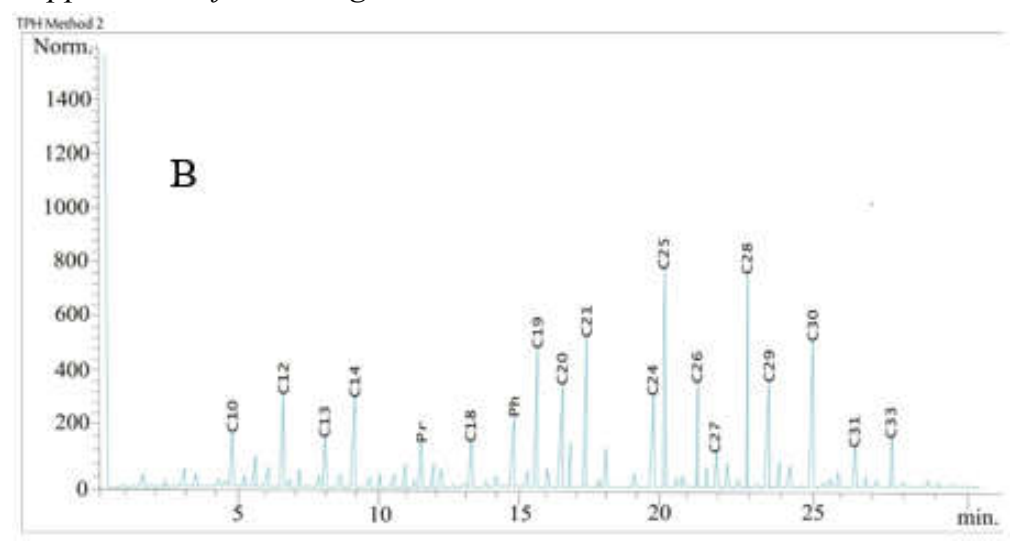

Fig. 9: Chromatogram of Total petroleum hydrocarbon (TPH) fractions of diesel polluted soil sample stimulated with cow dung for day 28 .

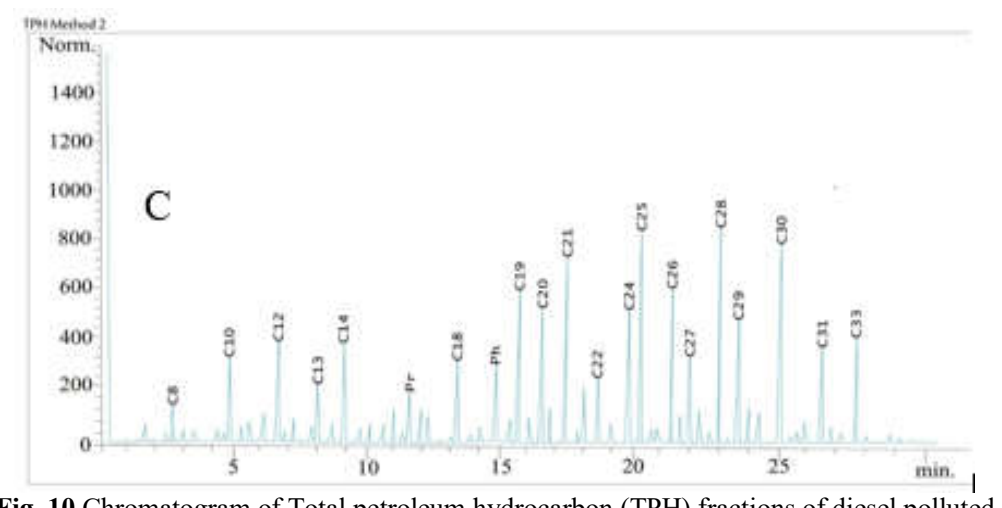

Fig. 10 Chromatogram of Total petroleum hydrocarbon (TPH) fractions of diesel polluted soil sample stimulated with sawdust for day 28 .

The hydrocarbon degrading bacteria isolates identified in the present study were Bacillus sp., Pseudomonas sp., Klebsiella sp., Alcaligenes sp., Enterobacter sp., Corynebacterium sp., Citrobacter sp., Escherichia coli, and Proteus sp (Table 2). These bacteria genera have been reported in hydrocarbon degradation by different authors (Onuoha et al., 2011; Abioye et al., 2012; Onuoha, 2013; Wokem et al., 2017). The TCHB populations and HUB populations as well as TF populations in the soil stimulated with cow dung and sawdust (organic wastes) were higher compared to un-stimulated control soil sample (Figs. 1-4). Similar results were reported by other researchers who observed counts of hydrocarbon utilizers in oil-polluted soil to be higher than in unpolluted soil samples (Ijah and Antai, 2003; Onuoha, 2013). The reason for the higher counts of bacteria may be due to the presence of appreciable quantities of nitrogen and phosphorus in the organic wastes (Figs 1-4). The increase in the population density of micro-organisms in hydrocarbon polluted media have been known to ensure rapid degradation of the pollutants (Skipper, 1999; Juhash et al., 2000; Odokuma and Akponah, 2010). On the other hand, the HUF isolates obtained in this study belonged to the genera: Fusaium sp., Aspergillus sp., Microsporium sp., Penicillium sp., and Mucor sp. (Table 3). These genera have also been reported by other researchers (Obire et al., 2008). The changes in physiochemical parameters during the bioremediation period showed substantial percentage decreases from day 0 to day 28 in both diesel polluted soil stimulated with cow dung and sawdust Table 4.These reductions indicated that the hydrocarbon degraders were actively utilizing the organic nutrient of nitrogen, phosphorus and potassium respectively. Similar observations have been made by Odokuma and Akpokodje (2004) and Odokuma and Okara (2005). The slight changes in the un-amended soil, control set up indicate that the indigenous micro-organisms in the diesel polluted soil were capable of utilizing the nutrients, but in low capacity, since there was no nutrient suplements to stimulate microbial growth as to enhance pollutant degradation. The $\mathrm{pH}$ showed reduction in values indicating increase in acidity in the unamended and amended soil samples. The observed reductions in $\mathrm{pH}$ in this study from low acidity to high acidity could be attributed to accumulation of waste products of metabolism and cell biomass by hydrocarbon degrading microbial population in the diesel oilcontaminated soil environment (Okpokwasili and Odokuma, 1990; Venosa et al., 1996; Macnaughton et al., 1999). The percentage losses in TPH observed in the diesel contaminated soil stimulated with cow dung and saw dust as well as the control (un-amended soil) is attributable to the biodegradability of the diesel oil in the contaminated soil by indigenous HUB and HUF in the soil enhanced by biostimulation with organic wastes (cow dung and sawdust). The highest \% loss in TPH was recorded on day 28 in soil amended with cow dung $(61.30 \%)$ and saw dust $(40.69 \%)$ (Table 5). Similar results were observed and reported in other studies (Bento et al., 2005; Onifade and Abubakar, 2007; Ibiene et al., 2011; Abioye et al., 2012; Chikere et al., 2011; Chikere et al., 2013). It is important to note that the two organic wastes used in this study were effective in bio-stimulating the hydrocarbon utilizing microorganisms which led to reduction in TPH of the soil polluted with diesel petroleum product, though cow dung was more effective than sawdust. 
From the results the residual \% loss in TPH recorded in the control un-stimulated soil sample on day 28 $(4.11 \%)$ Table 5 , could be attributable to natural attenuation processes, which includes evaporation, volatilization, photo-oxidation and bio-degradation. The loss in TPH due to natural attenuation at various time intervals have been reported (Venosa et al., 1996; Abu and Dike, 2008; Agarry and Ogunleye, 2012). The degradation of petroleum hydrocarbon involves a sequential reaction in which certain organisms may carry out the initial attack on the pollutant. This produces intermediate products that are subsequently utilized by other microbes, which eventually results in degradation (Banat, 2004; Olukunle and Boboye, 2013).

Conclusion: The study showed that cow dung as an organic waste has higher stimulant potential than sawdust in the biostimulation application in bioremediation of diesel fuel polluted soil environment, hence, the use of cow dung is recommended for efficient bioremediation of diesel polluted soil environment, since it is readily available and cost effective. However, different organic wastes which are abundant in the locality could be applied with cow dung in ecofriendly bioremediation of hydrocarbon contaminated environments.

\section{REFERENCES}

Abioye, OP; Agamuthus, P; Abdul-Aziz, AR (2012). Biodegradation of used lubricating oil by microbes isolated from pristine soil environment. Malays J. Sci., 3(1): 1-7

Abu, GO; Dike, PO (2008). A study of natural attenuation processes involved in a microcosm model of a crude oil impacted wetland sediment in the Niger Delta. Bioresource Technol., 99(11): 4671-4767

Adebusoye, SA; Ilori, MO; Amund, OO; Teni'ola, OD; Olatope, SO (2007). Microbial degradation of petroleum hydrocarbons in a polluted tropical stream. World J. Microbiol. Biotechnol. 23:11491159

Agary, SE; Ogunleye, O (2012). Box enhanced design application to study enhanced bioremedication of soil artificially contaminated with spent engine oil using biostimulation strategy. Int. J. Energy Environ. Engin., 12: 3-31

Agency for Toxic Substances and Disease RegistryATSDR (1995). Toxicological profile for fuel oils. Altlanta, GA. US Department of Health and Human Services, Public Health Service
Akpoveta, V; Osakwe, SA (2014). Determination of Heavy metal content of Refined Petroleum products. J. Appl. Chem. 7 (66): 01-02

Ali, N; Eliyas, M; Radwan, SS (2011). Hydrocarbon utilizing microorganisms naturally associated with saw dust. Sci. Direct., 83(9): 1268-1272

Amanchukwu, SC; Okpokwasili, GC; Obafemi A (1989). Factors affecting hydrocarbon degradation by schizosa-ccha-romyces pumbe. Isolated from palm wine. Proceedings of 1987 seminar on the petroleum industry and the Nigeria Environment pp. 154-160. Department of Petroleum Resources (DPR) and Nigerian National Petroleum Corporation (NNPC), Lagos, Nigeria

American Public Health Association-APHA (2005). Standard methods for the examination of water and waste water $20^{\text {th }}$ ed. Washington D.C American Waste Water Association. Water pollution control

American Society for Testing Materials- ASTME1943-98 (1998). Standard guide for remediation of soil by natural. Attenuation at Petroleum Release Sites. West Conshohcocken, Pennsylvania.

Banat, MI (2004). Microbial biodegradation. Microbiol. J. 53:61.

Barua, D; Buragohain, J; Sarma, SK (2011). Certain physico-chemical changes in the soil brought about by contamination of crude oil in two oil fields of Assam, North-East India. Europ. $J$. Exploit. Biol.1 (3):154-161.

Bento, FM; Camargo, AAO; Okeke, BC; FrankenBerger, WT (2005). Comparative bioremediation of soil contaminated with diesel oil by natural attenuation, biostimulation and bioaugmentation. Biores. Technol. 69: 1049-1055

Bergey, DN; Holt, JG (1994). Manual of determinative bacteriology $9^{\text {th }}$ ed. The Williams and Wilkins Company Baltimore.

Bundy, JG; Paton, GI; Campbell, CD (2002). Microbial communities in different soil types do not coverage after diesel contamination. J. Appl. Microbiol. 92: 276-288 
Cheesbrough, M (2006). District laboratory practice in Tropical Countries, Part 2, London, Cambridge University Press, 58-100

Chibuike, GU; Obiora (2014). Heavy metal polluted soils: Effect on plants and Bioremediation methods. Appl. Environ. Soil Sci. doi.org./10.1155/752708

Chikere, CB; Okpokwasili, GC; Chikere, BO (2011). Monitoring of microbial hydrocarbon remediation in the soil. Biotehnol. 1(3): 117-138.

Chikere, BO; Okpokwasili, GC (2013) Enhancement of Biodegradation of Petrochemicals by nutritent supplementation. Nig. J. Microbiol. 17:130-135

Chukwudozie, SO (2013). Stimulated Biodegradation of Spent Lubricating Motor Oil in Soil Amended with Animal Droppings. J. Nat. Sci. Res. 3(12): 2224-3186

Dadrasnia, A; Agamuthu, P (2010). Enhanced degradation of diesel-contaminated soil using organic wastes. Malays. J. Sci. 29: 225-230

Dadrasnia, A; Agamuthu, P (2013). Dynamics of diesel fuel degradation in contaminated soil using organic wastes. Int. J. Environ. Sci. Technol. 10: 769-778

David, E., Stephen, D., Alexious, H., Handike, R., Bartley, R (2007). Description of medical fungi $2^{\text {nd }}$ ed. Australia. National Library of Australia Cataloguing-in-publication, 15-204

Gong, Z; Li, P; Wilke, BM (2008). Effect of vegetable oil residue after soil extraction on physicochemical properties of sandy soil and plant growth. J. Environ Sci. 20: 1459-1462

Hawrot-Paw, A; Wijatkowski, A; Mikiciw, M (2015). Influence of diesel and biodiesel contaminated soil on microorganism, growth and development of plants. Plant Soil Environ. 61 (5): 189-194

Hilyard, EJ; Jones-Meehan, JM; Spargo, BJ; Hill, RT (2008). Enrichment, isolation and phylogenetic identification of polycyclic aromatic hydrocarbon degrading bacteria from Elizabeth river sediments. Applic. Envt. Microbiol. 74 (4):11761182

Ibiene, AA; Orji, FA; Ezidi, CO; Ngwobia, CL (2011). Bioremediation of hydrocarbon contaminated soil in Niger Delta using spent mushroom, compost and other organic wastes. Nigerian J. Agric. Food Environ. 7(3): 1-7

Ijah, UJJ; Antai, SP (2003). The potential use of chicken-drop microorganism for oil spill remediation. Environmentalist. 23(1): 89-95

Interstate Technology and Registry Council -ITRC (2014). Petroleum vapour instrusion; fundamental of screening, investigation and Management: PVI-1 Washington DC

Juhash, A; Stanely, GA; Brizt, ML (2000). Degradation of high molecular weight PAHs in contaminated soil by a bacterial Consortium: effects on microtox and mutagenicity bioassays. Biorem J. 4: 271-283

Knothe, G; Sharp, CA; Ryan, TW (2006. Exhaust Emission of Biodiesel, Petrodiesel neat mythyl esters and Alkanes in New Technology Engine. Energy and Fuels 20: 403-408

Leera, S; Ogugbue, CJ; Mbakwem-Aniebo, C (2018). Exploring the potentials of Nipa palm (Nypa frutican Ash and Rabbit dropping for enhanced $E x$ situ Bioremedia of crude oil contaminated soil. Asian J. Biotechnol. Biores. Technol. 3 (2): 1-17

Macnaughton, SJ; Stephen, JR; Venosa, AO; Davis, GA; Chang, YJ; White, DC (1999). Microbial population changes during bioremediation of an experimental oil spill. Appl. Environ. Microbiol. 65: $3566-3574$

Mukred, AM; Hamid, AA; Hamzah, A; Yusoff, WMW (2008). Development of three bacteria consortium for the Bioremediation of crude petroleum oil in contaminated water online $J$. Biol. Scis 8(4): 1608-4217

Nora, BS; Fari, M; Jose, AM; Waleed, AA; Huieb, HMR; Hauke, S (2013). Impact of long-term Diesel contamination on soil microbial community structure. J. Appl. Environ. Microbiol. 79 (2): 619-630

Obire, O; Anyanwu, EC; Okigbo, RN (2008). Saprophytic and crude oil degrading fungi from cow dung and poultry droppings as bioremediating agents. J. Agric. Technol. 4(92): 81-89

Odokuma, LO; Akpokodje, EG (2004). Biodegradation of Stimulated Landfill Leachate 
in Tropical soil of depth 6.5m. J. Appl. Sci. Technol. 4(1): 6-14

Odokuma, LO; Okara, JO (2005). Biodegradability of grounded cell phone recharge cards in two Niger Delta soils. J. Appl. Sci. Technol. 5 (1-2): 11-20

Okpokwasili, GC; Odokuma, LO (1990). Effects of Salinity on biodegradation of oil spill dispersants. Waste Manage.10: 141-146

Olukunle, OF; Boboye, B (2013). The molecular succession of bacterial community of crude oil polluted soil and water samples from the Niger Delta Nigeria. British J. Appl. Sci. Technol. 3(4): 777-781

Omoni, VT; Aguoru, CU; Edoh, EO; Makinde, O (2015). Biostimulation of hydrocarbon utilizing bacteria in soil contaminated with spent engine oil using banana and plantain agro-wastes. J. Soil Sci. Environ. Manage. 6 (8): 225-233

Onifade, AK; Abubakar, FA (2007). Characterization of hydrocarbon degrading microorganisms isolated from crude oil contaminated soil and remediation of the soil by enhanced Natural attenuation. Research J. Biol. Sci. 2 (1): 149-155

Onuoha, SC; Olugbue, VU; Uraku, JA; Uchendu, DO (2011). Biodegradation Potentials of Hydrocarbon degraders from waste-lubricating oil spilled soils in Ebonyi State, Nigeria. Int. J. Agric. Biol. 13: 586-590

Onuoha, SC (2013). Stimulated Biodegradation of Spent Lubricating Motor oil in soil Amended with Animal Droppings. J. Nat. Sci. Res. 3 (12): 106116

Skipper, HD (1999). Bioremediation of Contaminated soils. In: Syliva DM (Ed.). Principles and Applications of Soil Microbiology. Prentice Hall, Upper Saddle River, New York, 469-481
Sterwart, EA; Maxcrinshaw, H; Parkinson, JA; Quarmby, C (1974). Chemical Analysis of Ecological Materials, Blackwell Scientific Publication, Oxford, London

Sylvia, A; Kalamdhad, AS (2019). Effects of heavy metals on soil, Human Health and Aquatic Life. Int. J. Res. Chem. Environ. 1 (2): 15-21

Venosa, AD; Suidan, MT; Warenn, BA; KingStrohemjen, KL; Haines, JR; Eberhart, BL; Holder, E (1996). Bioremediation of Experimental oil spill on the shoreline of Decaware Bay. Environ. Sci. Technol. 30:17641775

Vidali, M (2001). Bioremediation: An Overview Pure and Appl. Chem., 73(7):1163-1172

Wellington, BF; Asmus AF (1995). Diesel engines and fuel systems. Longman, Australia

Wokem, VC; Odokuma, LO; Ariole, CN (2017). Isolation and characterization of hydrocarbonutilizing bacteria from petroleum sludge samples obtained from crude oil processing facility in Nigeria. J. Appl. Environ. Manage. 21(2): 355359

Zaki, MS; Authman, MNN; Ata, NS; Abdelzaher, MF; Hamman, AM (2014). An effect of environmental oil spills on commercial fish and shellfish in Suez Canal and Suez Golf regions. Life Sci. J. 11 (2): 269-274. 